\title{
Randomized controlled trial of Hepatitis B virus vaccine in HIV-I-infected patients comparing two different doses
} Patricia Cornejo-Juárez ${ }^{* \dagger 1}$, Patricia Volkow-Fernández ${ }^{\dagger 1}$, Kenia EscobedoLópez $^{2}$, Diana Vilar-Compte ${ }^{1}$, Guillermo Ruiz-Palacios ${ }^{2}$ and Luis Enrique Soto-Ramírez ${ }^{\dagger 2}$

\author{
Address: ${ }^{1}$ Infectious Diseases, Instituto Nacional de Cancerología, Mexico City, México. Av. San Fernando No. 22, Col. Sección XVI, Tlalpan, 14000 \\ México, D.F, Mexico and 2Infectious Diseases, Instituto Nacional de Ciencias Médicas y de la Nutrición. Salvador Zubirán, Mexico City, Mexico \\ Email: Patricia Cornejo-Juárez* - patcornejo@yahoo.com; Patricia Volkow-Fernández - volkow@perezpadilla-volkow.com.mx; Kenia Escobedo- \\ López - kemesk@yahoo.com; Diana Vilar-Compte - diana-vilar@yahoo.com.mx; Guillermo Ruiz-Palacios - gmrps@servidor.unam.mx; \\ Luis Enrique Soto-Ramírez - lsoto@quetzal.innsz.mx \\ * Corresponding author †Equal contributors
}

Published: 06 April 2006

AIDS Research and Therapy2006, 3:9 doi:10.1186/1742-6405-3-9
Received: 18 October 2005

Accepted: 06 April 2006

This article is available from: http://www.aidsrestherapy.com/content/3/1/9

(c) 2006Cornejo-Juárez et al; licensee BioMed Central Ltd.

This is an Open Access article distributed under the terms of the Creative Commons Attribution License (http://creativecommons.org/licenses/by/2.0), which permits unrestricted use, distribution, and reproduction in any medium, provided the original work is properly cited.

\begin{abstract}
Background: Co-infection with hepatitis B virus (HBV) and human immunodeficiency virus (HIV) is not infrequent as both share same route of exposure. The risk of developing chronic hepatitis $B$ virus is $6 \%$, in general population but can reach $10-20 \%$ in HBV/HIV co-infected patients. When compared to general population, the response rate to HBV vaccine in HIV-infected patients is diminished, so previous studies have tried to improve this response using variety of schedules, doses and co-administration of immunomodulators. The purpose of this study was to evaluate two doses of recombinant HBV vaccine (I0 or $40 \mu \mathrm{g})$, IM at $0, \mathrm{I}$ and 6 months. Vaccination response was measured 30-50 days after last dose; titers of $>9.9 \mathrm{IU} / \mathrm{L}$ were considered positive.
\end{abstract}

Results: Seventy-nine patients were included, 48 patients $(60.7 \%)$ serconverted. Thirty-nine patients $(49.3 \%)$ received $10 \mu \mathrm{g}$ vaccine dose, 24 patients $(61.5 \%)$ seroconverted. Forty patients $(50.7 \%)$ received $40 \mu \mathrm{g}$ vaccine dose, $24(60 \%)$ seroconverted. There were no differences between two doses. A statistically significant higher seroconversion rate was found for patients with CD4 cell counts at vaccination $\geq 200 \mathrm{cel} / \mathrm{mm} 3$ (33 of 38 patients, $86.8 \%$ ), compared with those with CD4 $<200 \mathrm{cel} / \mathrm{mm} 3$ (I5 of $4 \mathrm{I}, 36.6 \%$ ), [OR II.44, 95\% IC 3.67-35.59, $\mathrm{p}=0.003$ ], there were no differences between two vaccine doses. Using the logistic regression model, $\mathrm{CD}_{4}$ count $<200 \mathrm{cel} /$ $\mathrm{mm}^{3}$ were significantly associated with non serologic response $(p=0.003)$. None other variables such as gender, age, risk exposure for HIV, viral load, type or duration of HAART or AIDS-defining illness, were asociated with seroconversion.

Conclusion: In this study, an increase dose of HBV vaccine did not show to increase the rate of response in HIV infected subjects. The only significant findings associated to the response rate was that a CD4 count $\geq 200 \mathrm{cel} / \mathrm{mm}^{3}$, we suggest this threshold at which HIV patients should be vaccinated. 


\section{Background}

Hepatitis B virus (HBV) is one of the major causes of acute and chronic hepatitis worldwide that can be prevented by immunization $[1,2]$.

Co-infection with HVB and human immunodeficiency virus (HIV) is frequent as both share the same routes of transmission [3]. In general population, risk of developing chronic hepatitis is $6 \%$, but it can reach $10-20 \%$ in HBV/HIV co-infected patients, besides this HBV/ HIV patients present a higher level of HBV replication and potential of transmission is increased [2,4-8]. HBV infection has been associated with more rapid progression to AIDS, explained by an increased expression of HIVinfected cells and faster decrease in CD4 lymphocytes [912].

When compared to general population, the response rate to HBV vaccine in HIV-infected patients, is diminished $(40-60 \%$ vs $60-80 \%)[10,13]$. This lower response is related with CD4 count less than $500 \mathrm{cel} / \mathrm{mm} 3$, and has also been found with other antigens like influenza or pneumococcal vaccines $[14,15]$.

In previous studies including patients under hemodialysis, the rate of response to HBV vaccine has been significantly augmented by increasing dose, giving a fourth dose of the vaccine or using immunomodulators agents such as levamisole [2,16]. In HIV-patients the use of granulocytemacrophage colony-stimulating factor (GM-CSF) concurrent with HBV vaccine, has shown a significant increase in seroconversion rate and in anti-HBs titers [17].

Currently, there are no data to determine the best HBV vaccine schedule for HIV-infected patients. With the aim to evaluate the rate of response to two different concentration of HBV vaccine in HIV-infected patients, we conducted a controlled, randomized, clinical trial. We also evaluated HIV viral load and $\mathrm{CD}_{4}$ counts at the time of vaccination.

\section{Methods}

We conducted a double blind, randomized, controlled trial using two different concentrations of $\mathrm{HBV}$ vaccine 10 or $40 \mu$ gs (Recombivax, HB, Merck, Sharp \&Dohme, USA), in two groups of HIV-infected patients stratified by CD4 count at time of vaccination $\left(<200\right.$ or $\left.\geq 200 \mathrm{cel} / \mathrm{mm}^{3}\right)$ attending an HIV/AIDS Clinic at the Instituto Nacional de Ciencias Médicas y de la Nutrición Salvador Zubirán and at the Instituto Nacional de Cancerología in Mexico City. The study was reviewed and approved by the Institutional Committee of Human Biomedical Investigation (CIBH: 860 and CFEI: INF-0599900-1, approved on December 1999).
We included HIV-infected patients $>16$ years of age, negative for any HBV serological marker, not previously vaccinated, without active opportunistic infection at the time of vaccination, who accepted to participate and signed informed consent.

Patients were randomized to receive 10 or $40 \mu \mathrm{g}$ of HBV recombinant vaccine, $1 \mathrm{ml}$ intramuscularly in the deltoid region at 0,1 and 6 months. We collected data on age, gender, route to exposure for HIV infection, date for HIV infection diagnosis, CD4 count and HIV viral load at the first vaccine dose, type and time (in months) under antiretroviral treatment and AIDS-defining event.

A technician who ignored vaccine dose, administered the vaccine and collected a serum sample $40 \pm 10$ days after third-dose application.

Quantitative anti-HBs test by IU/L (Microelisa system, Hepanostika ${ }^{\circledR}$ Anti-HBs New, Organon Tecknika, The Netherlands) was performed. Negative samples for quality assurance were included. All sera were tested simultaneously. Response to vaccination was considered when there was a rise in anti-HBs titers $\geq 10 \mathrm{IU} / \mathrm{L}$. The absolute count of CD4 lymphocytes was determined by a fuorescence-activate cell analyzer, using monoclonal antibodies. The quantization of HIV-1 RNA was measured by AMPLICOR HIV-1 MONITOR ${ }^{\circledR}$ test was from 40 to 750,000 RNA copies $/ \mathrm{mL}$.

\section{Statistical analysis}

We calculated an estimated $60 \%$ seroconversion rate for the standard dose, an increase of $20 \%$ for the double dose to be clinically significant. Eighty patients in each group was required for a clinically difference.

We calculated seroconversion rate for each vaccine dose by mean \pm standard deviation for Student $t$ test or MannWhitney test for continuous variables were used as appropriate. For discrete variables, we used Chi-square or Fisher exact test and reported odds ratios (ORs) with 95\% confidence interval $(95 \% \mathrm{CI})$. P values $\leq 0.05$ were considered statistically significant.

Univariate analysis was used to test for associations between independent (age, gender, vaccine dose, CD4 count and viral load at time of vaccination, time in months from HIV diagnosis, treatment with HAART and AIDS-defining event) and dependent variable (seroconversion). A logistic regression model and a Cox model were performed.

\section{Results}

Patients were recruited between April 1999 and May 2000. Eighty four patients were included. Five (6\%) were 
Table I: Characteristics of HIV-infected patients. Baseline clinical and demographic characteristics of HIV-infected patients, who completed the study $(n=79)$

\begin{tabular}{|c|c|c|c|}
\hline Variables & Vaccine $10 \mu \mathrm{g}$ & Vaccine $40 \mu \mathrm{g}$ & $\mathbf{p}$ \\
\hline No. patients (\%) & $39(49.3)$ & $40(50.7)$ & - \\
\hline Gender male - No. (\%) & $27(69.2)$ & $29(72.5)$ & 0.749 \\
\hline Mean age (years \pm s.d.) & $35.6 \pm 8.12$ & $34.1 \pm 7.6$ & 0.378 \\
\hline \multicolumn{4}{|l|}{ HIV exposure - No. (\%) } \\
\hline Heterosexual & $18(45 \%)$ & $16(41 \%)$ & 0.721 \\
\hline Homo or bisexual & $22(55 \%)$ & $23(59 \%)$ & \\
\hline Diagnosis of HIV (months \pm s.d.) & $40.6 \pm 35.4$ & $40.2 \pm 32.65$ & 0.960 \\
\hline Mean CD4 count (cel/mm \pm s.d.) & $245 \pm 217.9$ & $225.45 \pm 189.7$ & 0.671 \\
\hline \multicolumn{4}{|l|}{ CD4 cel/mm³ / No. (\%) } \\
\hline$<200$ & $20(51.3 \%)$ & $21(52.5 \%)$ & 0.914 \\
\hline$\geq 200$ & $19(48.8 \%)$ & $19(47.5 \%)$ & \\
\hline Viral load (copies/mL) & $75,187 \pm 153,305$ & $67,335 \pm 112,742$ & 0.811 \\
\hline \multicolumn{4}{|l|}{ Viral load (copies/mL) - No. (\%) } \\
\hline$\leq 400$ & $6(20 \%)$ & $9(25 \%)$ & 0.860 \\
\hline $400-\leq 20,000$ & II (36.6\%) & II (30.6\%) & \\
\hline$\geq 20,000$ & $13(43.3 \%)$ & $16(44.4 \%)$ & \\
\hline AIDS-defining illness - No. (\%) & $17(43.6)$ & $10(25)$ & 0.082 \\
\hline $\begin{array}{c}\text { Treatment with HAART* }- \text { No. } \\
\text { (\%) }\end{array}$ & $22(56.4)$ & $29(72.5)$ & 0.135 \\
\hline $\mathrm{PI}$ & $20(5 \mathrm{I} .2)$ & $23(57.5)$ & \\
\hline NNRTI & I (2.6) & $4(10)$ & \\
\hline $\mathrm{PI}+\mathrm{NNRTI}$ or $3 \mathrm{NRTI}$ & I (2.6) & $2(5)$ & \\
\hline
\end{tabular}

PI: Protease inhibitor; NNRTI: non-nucleoside reverse transcriptase inhibitor; NRTI: Nucleoside reverse transcriptase inhibitor.

lost during follow-up [two (2.4\%) in $10 \mu \mathrm{g}$ dose and three (3.6\%) in $40 \mu \mathrm{g}$ dose]. Characteristics of subjects who completed the study and those who dropped out were similar.

Non significant differences were found among demographic variables between the two groups. Age, gender, CD4 count at vaccination, HIV viral load, history of an AIDS defining event and antiretroviral therapy for each group are depicted in Table 1.

The overall seroconversion rate after $\mathrm{HBV}$ vaccination was $60.7 \%$ (48 of 79 patients). For $10 \mu \mathrm{g}$ vaccine dose, 24 of 39 patients $(61.5 \%)$ seroconvert; and for $40 \mu \mathrm{g}$ vaccine dose, 24 of 40 patients $(60 \%)$. Non significant difference was found between two different vaccine concentrations [relative risk $(\mathrm{RR})=1.1 ; 95 \%$ confidence interval $(\mathrm{CI})=$ $0.61-1.98, \mathrm{p}=0.889$ ].
Stratified by CD4 count, 33 of 38 patients (86.8\%) with CD $4 \geq 200 \mathrm{cel} / \mathrm{mm} 3$ seroconverted, compared with 15 of 41 patients with $<200 \mathrm{cel} / \mathrm{mm} 3(36.5 \%),(\mathrm{OR}=11.4$, $95 \% \mathrm{CI}=3.6-35.6, \mathrm{p}=0.003)$. Stratified by viral load, 12 of 15 patients with $<400$ copies/mL seroconverted $(80 \%)$, and 30 of 51 patients with $\geq 400$ copies/mL (58.8\%), (OR $0.45,95 \% \mathrm{CI}=0.22-0.92, \mathrm{p}=0.29)$.

Patients with CD4 $<200 \mathrm{cel} / \mathrm{mm} 3$ and viral load $<400$ copies/mL, showed higher seroconversion rates, but only CD4 count was statistically significant. No diference was observed with two different vaccine doses.

Variables included in the logistic regression model were vaccine dose, CD4 count, viral load, HAART treatment, AIDS-defining illness, gender and risk factor for HIV infection. Only CD4 count $<200 \mathrm{cel} / \mathrm{mm} 3$ was associated with non seroconversion. 


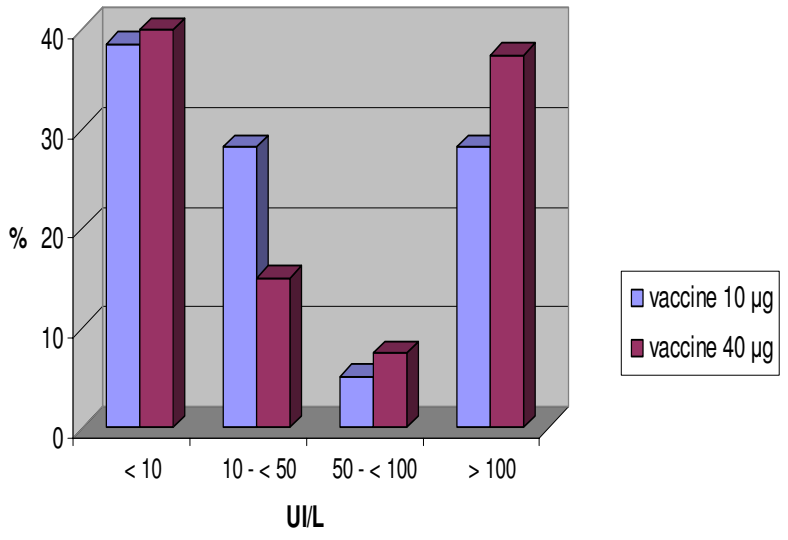

Figure I

Titers post-vaccination. Titers post-vaccination categorized in four groups, with two different vaccine concentrations $(\mathrm{Ul} / \mathrm{mL})$.

Mean anti-HBs titers were $137.3 \pm 56.7 \mathrm{IU} / \mathrm{L}$ for the $10 \mu \mathrm{g}$ vaccine dose and $144.1 \mathrm{IU} / \mathrm{L} \pm 56.7$ for the $40 \mu \mathrm{g}$ vaccine dose $(\mathrm{p}=\mathrm{ns})$. Titers post-vaccination are shown in Figure 1 . Titers were significantly higher in patients with CD4 $\geq$ $200 \mathrm{cel} / \mathrm{mm}^{3}$ compared with those with CD4 $<200 \mathrm{cel} /$ $\mathrm{mm}^{3}(107.2 \pm 56.7 \mathrm{IU} / \mathrm{L}$ vs $39.7 \pm 35.4 \mathrm{IU} / \mathrm{L}, \mathrm{p}<0.005)$.

HBV vaccine was well tolerated by all patients; two patients reported pain at the injection site, one with erythema. No serious adverse events were registered.

\section{Discussion}

Approximately $90-97 \%$ of healthy adults will show protective anti-HBs titers after vaccination with recombinant HBV vaccine $[18,19]$. As previously reported $[7,20,21]$, we found a lower rate of response in this cohort of HIVinfected patients vaccinated with HBV recombinant vaccine $(60.7 \%)$ of the population fully immunized, increasing vaccine did not have a beneficial effect.
Risk factors significantly associated to failure of vaccination in previously reports, were the degree of immunosuppression and clinical markers of advanced HIV disease like CD4 count at vaccination and history of an AIDS-defining event. We found that the factor most strongly associated with non seroconversion and lower anti-HBs titers was $\mathrm{CD}_{4}$ count $<200 \mathrm{cel} / \mathrm{mm}^{3}$. Previous studies with other antigens (like influenza or 23-valent pneumococcal vaccines) have shown lesser response asocciated with lower CD4 counts $[14,15]$.

There are numerous reports describing a variety of dose schedules, limited success and markers associated with impaired response to $\mathrm{HBV}$ vaccine in these individuals. Most studies have been small in size sample making it difficult to draw conclusions within and between studies. Recently Fonseca et al, found higher serconversion with double vaccine dose in those patients with CD4 count $\geq$ $350 \mathrm{cel} / \mathrm{mm}^{3}$ and low HIV viremia, with no differences between two different vaccine doses in patients with CD4 $<350 \mathrm{cel} / \mathrm{mm}^{3}$ [22].

This study was performed with a smaller sample that initially calculated as we found trouble in getting non vaccinated or non infected HBV patients. Because of the small size, the power to determine differences between the two dosages of vaccine is low resulting in the possibility of a type II error. We found that the CD4 nadir $(<200 \mathrm{cel} /$ $\mathrm{mm}^{3}$ ) of patients whose $\mathrm{CD}_{4}$ increase with HAART over $\geq$ 200 had a similar rate of response when compared to patients with persistent $\mathrm{CD}_{4} \geq 200 \mathrm{cel} / \mathrm{mm}^{3}$ (data not presented); this finding should be interpreted with caution, it could be related to the small sample size. One interesting point is to investigate in the future the duration of this increase to achieve best rate of response in HIV-infected patients receiving HAART.

No seroconversion differences were found between this risk groups among homosexual, bisexual or heterosexual patients as has previously reported in other studies $[1,2,18,20]$. In this sample no patients had a history of drug abuse probably to the low number of HIV infected patients associated to this risk factor in Mexico less than

Table 2: Logistic regression model. Independent variables associated with non-seroconversion

\begin{tabular}{cccc}
\hline & OR $^{*}$ & OR adjusted [Cl ${ }_{95 \%]}$ & P \\
\hline Vaccine dose $10 \mu \mathrm{g}$ & - & $0.937 \pm 0.432[0.27-2,31]$ & 0.889 \\
CD4 $<200 \mathrm{cel} / \mathrm{mm} 3$ & $1.21[0.3-4.9]$ & $11.44 \pm 6.62[3.67-35.59]$ & 0.003 \\
Viral load $\geq 40$ copies/mL & $0.82[0.17-3.82]$ & $0.451 \pm 0.164[0.22-0.92]$ & 0.029 \\
Non HAART treatment & $0.58[0.15-2.23]$ & $0.649 \pm 0.201[0.35-1.19]$ & 0.164 \\
AIDS-defining illness & $2.5[0.54-12.29]$ & $0.972 \pm 0.333[0.49-1.9]$ & 0.934 \\
Gender male & $0.75[0.13-4.27]$ & $0.806 \pm 0.266[0.42-1.54]$ & 0.517 \\
Homosexual or bisexual & $0.6[0.16-2.2]$ & $0.844 \pm 0.251[0.47-1.51]$ & 0.569 \\
\hline
\end{tabular}

$* \mathrm{OR}=$ odds ratio 
$1 \%$. None other risk factors as age, gender, type or duration of HAART or history of AIDS-defining event were related with serconversion.

We did not find any serious adverse event related with $\mathrm{HBV}$ vaccination in this group of patients as HIV and HBV share the same routes of exposure, we recommend vaccinating HIV patients against HBV.

\section{Conclusion}

Although the sample study is small to give a definite conclusion, increasing the does not appears to contribute to HVB vaccine seroconversion. This study confirms previous reports that HIV-infected patients have a poor immunologic response to $\mathrm{HBV}$ vaccine, but a CD4 count threshold is $\geq 200 \mathrm{cell} / \mathrm{mm}^{3}$ appears to increase vaccination response independently to vaccine dosing, as has been show by other studies.

\section{Competing interests}

The author(s) declare that they have no competing interests.

\section{Authors' contributions}

PCJ- Participated in the design of the study, collected data, wrote the manuscript

PVF- Revising the manuscript, statistical analysis

KEL- Carried out immunoassays

DVC- Statistical analysis and revising the manuscript

GRP- Revising the manuscript critically for important intellectual content

LESR- Analysis and interpretation of data, revising the manuscript critically for important intellectual content

All authors read and approved the final manuscript.

\section{Acknowledgements}

We are indebted to Dr. Rogelio Pérez-Padilla and Alejandro Cabrera for advice on statistical analysis, and Merck Sharp \& Dohme for the vaccine donation (Recombivax).

\section{References}

I. Biggar R, Goedert J, Hoofnagle J: Accelerated loss of antibody to hepatitis B surface antigen among immunodeficient homosexual men infected with HIV. N Engl J Med I 987, 3 I 6:630-63I.

2. Hadler SC, Judson FN, O'Malley PM, Altman NL, Penley K, Buchbinder S, Schable CA, Coleman PJ, Ostrow DN, Francis DP: Outcome of hepatitis $B$ virus infection in homosexual men and its relation to prior human immunodeficiency virus infection. J Infect Dis 1991, 163:454-459.

3. Bruguera M, Cremades M, Salinas R, Costa J, Grau M, Sans J: Impaired response to recombinant hepatitis $B$ vaccine in HIV-infected persons. J Clin Gastroenterol 1992, I4:27-30.
4. Lazizi Y, Grangeot-Keros L, Delfraissy J, Boue F, Dubreuil P, Badur S, Pillot J: Reappearance of hepatitis $B$ virus in immune patients infected with the human immunodeficiency virus type I. J Infect Dis 1988, I 58:666-667.

5. Hadler S: Hepatitis B prevention and human immunodeficiency virus (HIV) infection. Ann Intern Med 1988, 109:92-94.

6. Poles M, Lew E, Dieterich D: Diagnosis and treatment of hepatic disease in patients with HIV. Gastroenterol Clin North Am 1997, 26:29I-32I.

7. Pomerantz R, Friedman L: Hepatitis $B$ and human immunodeficiency virus: double trouble. Gastroenterology 1991, I0 1:862-863.

8. Bodsworth N, Cooper D, Donovan B: The influence of human immunodeficiency virus type I infection on the development of the hepatitis B virus carrier state. J Infect Dis I99|, 163: I |38-I I 40.

9. Koblin B, Taylor P, Rubinstein P, Stevens C: Effect of duration of hepatitis $B$ virus infection on the association between human immunodeficiency virus type- $I$ and hepatitis B viral replication. Hepatology 1992, I5:590-592.

10. Eskild A, Magnus P, Petersen G, Sohlberg C, Jensen F, Kittelsen P, Skaug K: Hepatitis B antibodies in HIV-infected homosexual men are associated with more rapid progression to AIDS. AIDS 1992, 6:57I-574.

II. Horvath J, Raffanti S: Clinical aspects of the interactions between human immunodeficiency virus and the hepatotropic viruses. Clin Infect Dis 1994, 18:339-4I0.

12. Bodsworth N, Donovan B, Nightingale B: The effect of concurrent human immunodeficiency virus infection on chronic hepatitis B. A study of $\mathbf{1 5 0}$ homosexual men. J Infect Dis 1989, 160:577-582.

13. Collier A, Corey L, Murphy V, Handsfield H: Antibody to human immunodeficiency virus (HIV) and suboptimal response to hepatitis B vaccination. Ann Intern Med 1988, 109:101-105.

14. Malaspina A, Moir S, Orsega SM, Vasquez J, Miller NJ, Donoghue ET, Kottilil S, Gezmu M, Follmann D, Vodeiko GM, Levandowski RA, Mican JM, Fauci AS: Compromised B cell responses to influenza vaccination in HIV-infected individuals. J Infect Dis 2005, 191:1442-1450.

15. Rodriguez-Barradas MC, Alexandraki I, Nazir T, Foltzer M, Musher DM, Brown S, Thornby J: Response of human immunodeficiency virus-infected patients receiving highly active antiretroviral therapy to vaccination with 23 -valent pneumococcal polysaccharide vaccine. Clin Infect Dis 2003, 37:438-447.

16. Kayatas M: Levamisole treatment enhances protective antibody response to hepatitis $B$ vaccination in hemodialysis patients. Artif Organs 2000, 26:492-496.

17. Sasaki MG, Foccacia R, de Messias-reason IJ: Efficacy of granulocyte-macrophage colony-stimulating factor (GM-CSF) as a vaccine adjuvant for hepatitis B virus in patients with HIV infection. Vaccine 2003, 21:4545-4549.

18. Hadler S, Francis D, Maynard J: Long-term immunogenicity and efficacy of hepatitis B vaccine in homosexual men. N Engl J Med 1986, 315:209-2।4.

19. Beekmann S, Doebbeling B: Frontiers of occupational health. New vaccines, new prophylactic regimens, and management of the HIV-infected worker. Infect Dis Clin North Am 1997, II:313-329.

20. Carne C, Weller IV, Waite J, Briggs M, Pearce F, Adler MW, Tedder RS: Impaired responsiveness of homosexual men with HIV antibodies to plasma derived hepatitis B vaccine. $\mathrm{Br}$ Med J 1987, 294:866-868.

21. Hollinger B: Hepatitis B virus. In Viral Hepatitis 2nd edition. Edited by: Hollinger B, Robinson W, Purcell R, Gerin J, Ticehurst J. New York: Raven Press; 1999:73-138.

22. Fonseca MO, Pang LW, de Paula Cavalheiro N, Barone AA, Heloisa Lopes M: Randomized trial of recombinant hepatitis $B$ vaccine in HIV-infected adult patients comparing a standard dose to a double dose. Vaccine 2005, 23:2902-2908. 